\title{
Ultrasound assisted osmotic dehydration of organic cranberries (Vaccinium oxycoccus): Study on quality parameters evolution during storage
}

\author{
M. Nowacka ${ }^{\text {a }}$, U. Tylewicz ${ }^{\text {b, * }}$, S. Tappi ${ }^{\text {c }}$, L. Siroli ${ }^{\text {c }}$, R. Lanciotti ${ }^{\text {b, c }}$, S. Romani ${ }^{\text {b, c }}$, \\ D. Witrowa-Rajchert ${ }^{\mathrm{a}}$ \\ ${ }^{a}$ Faculty of Food Sciences, Department of Food Engineering and Process Management, Warsaw University of Life Sciences (WULS-SGGW), Warsaw, Poland \\ ${ }^{\mathrm{b}}$ Department of Agricultural and Food Sciences, Alma Mater Studiorum, University of Bologna, Campus of Food Science, Cesena, Italy \\ c Interdepartmental Centre for Agri-Food Industrial Research, Alma Mater Studiorum, University of Bologna, Campus of Food Science, Cesena, Italy
}

\section{A R T I C L E I N F O}

\section{Article history:}

Received 28 February 2018

Received in revised form

1 May 2018

Accepted 5 May 2018

Available online 11 May 2018

\section{Keywords:}

Cranberry

Osmotic dehydration

Shelf life

Microbiology

Water activity

Colour

\begin{abstract}
A B S T R A C T
Cranberries are appreciated for their high amount of antioxidants such as flavonoids, anthocyanins, phenolic acids, carotenoids and vitamins. However, due to their sour and tart taste they request to be processed into sweeter dried fruits in order to be acceptable for the consumers. The aim of this work was to analyse the effect of ultrasound assisted osmotic dehydration on mass transfer parameters and on quality characteristics during storage of cranberries. Ultrasound treatment was performed at the frequency of $21 \mathrm{kHz}$ for $30 \mathrm{~min}$ in three osmotic solutions - 61.5\% sucrose, 30\% sucrose with an addition of $0.1 \%$ of steviol glycosides and $40 \%$ trehalose on cut in half cranberries. Afterwards, the cranberry samples were subjected to osmotic dehydration process at $40^{\circ} \mathrm{C}$ for $72 \mathrm{~h}$. The osmodehydrated samples both with or without ultrasound pre-treatment were collected and stored at $10^{\circ} \mathrm{C}$ in climatic chamber in microperforated plastic bags (PLA) for 8 weeks. The weight reduction, dry matter, water activity, colour, and microbiological analysis were performed after 1, 2, 4 and 8 weeks of storage. The obtained results indicated that ultrasound application significantly affected the mass transfer parameters during osmotic treatment, as well as it did the type of osmotic solution used. Thermal analysis showed variations in sugar melting temperature and enthalpy as a result of osmotic treatment and storage. During the storage, lower weight loss and higher lightness were observed in US pre-treated samples. The sample that preserved the best chemico-physical and microbiological characteristics during storage was the one treated with $61.5 \%$ sucrose solution, due to its lowest water activity.
\end{abstract}

() 2018 Elsevier Ltd. All rights reserved.

\section{Introduction}

Cranberries are considered as a rich source of many compounds which have a positive impact on human health. This fruit contains vitamins (A, C, E), minerals (potassium, sodium, selenium), fiber, lutein and beta-carotene. However, the most represented substances in cranberry fruit are polyphenols (Blumberg et al., 2013; McKay, Chen, Zampariello, \& Blumberg, 2015; Neto, 2007; Nowacka, Fijalkowska, Dadan, et al., 2018; Teleszko, 2011). Unfortunately, fresh cranberries have a very sour and tart flavor that

* Corresponding author. Department of Agricultural and Food Sciences, Alma Mater Studiorum, University of Bologna, Campus of Food Science, Piazza Goidanich, 60, 47521 Cesena, Italy.

E-mail address: urszula.tylewicz@unibo.it (U. Tylewicz). makes them rarely eatable as raw fruits. Although sugar is generally not desirable in the diet, according to American nutritional recommendations, its use is applied to improve the taste of products with highly valuable nutritional values to make them acceptable for the consumer (Blumberg et al., 2013; Kowalska \& Olejnik, 2016; Nowacka, Fijalkowska, et al., 2017). Recently, different substances such as sweeteners or sweetness enhancer were proposed as an alternative to the use of sucrose. One of them is steviol glycoside, which is approximately 300 times sweeter than sucrose and it is highly appreciated for its technological purpose, since it is temperature and $\mathrm{pH}$ stable during the processing and storage (Periche, Castelló, Heredia, \& Escriche, 2015).

To obtain appropriate sweetness of the final product, fresh cranberries are subjected to osmotic dehydration (OD) process Nowacka, Fijalkowska, Wiktor, et al., 2018). OD is a widely used 
process carried out in hypertonic solution, usually sugars. During $\mathrm{OD}$, a mass exchange occurs, in particular, water flows out from the fresh tissue into the surrounding solution and the osmotic substance enters the dehydrated tissue. The result is a partial dewatering impregnation, which allows an increase of the shelf-life of OD material (Goula, Kokolaki, \& Daftsiou, 2017; Kaymak-Ertekin, F. \& Sultanolu, 2000; Nowacka, Śledź, Wiktor, \& Witrowa-Rajchert, 2014; Radojčin et al., 2015; Rząca, Witrowa-Rajchert, Tylewicz, \& Rosa, 2009; Tylewicz et al., 2011). However, this process is long and often requires the acceleration of mass transfer using traditional methods as agitation and rotation or new techniques as for example ultrasound (Deng \& Zhao, 2008; Fernandes, Oliveira, \& Rodrigues, 2008; Goula et al., 2017; Nowacka, Tylewicz, Laghi, Dalla Rosa, \& Witrowa-Rajchert, 2014). Ultrasound (US) is an air vibration in the frequency from $20 \mathrm{kHz}$ to $100 \mathrm{MHz}$. In liquid medium it results in compression and expansion of material, called "sponge effect", and formation of cavitation bubbles. The application of ultrasound may have an influence on physical and chemical properties of plant tissue due to creation of microscopic channels and formation of free radicals (Goula et al., 2017; Knorr, Zenker, Heinz, \& Lee, 2004; McClements, 1995; Nowacka, Fijalkowska, Dadan, et al., 2018; Simal, Benedito, Sánchez, \& Rosselló, 1998; Witrowa-Rajchert, Wiktor, Sledz, \& Nowacka, 2014). Moreover, ultrasound coupled with thermal treatment leads to better bacterial inactivation in comparison to only thermal treatment (Zenker, Heinz, \& Knorr, 2003).

It is recognized that quality characteristics and physical properties of food may undergo changes during US treatment (Fernandes, Gallão, \& Rodrigues, 2009; Fernandes, Gallão, et al., 2008; Goula et al., 2017; Kentish \& Ashokkumar, 2011; Nowacka, Fijalkowska, Dadan, et al., 2018; Rajewska \& Mierzwa, 2017) and OD process (Fernandes et al., 2009; Nowacka, Tylewicz, Romani, Dalla Rosa, \& Witrowa-Rajchert, 2017), but also during further storage (Wang, 2006). However, while changes due to process have received more attention, evolution of quality during storage of these type of product are seldom assessed. Thus, the aim of this study was to investigate the effect of ultrasound assisted osmotic dehydration on cranberries mass exchange parameters and on their quality parameters (dry matter, water activity, colour, thermal behaviour and microbial growth) during storage.

\section{Material and methods}

\subsection{Sample preparation}

Fresh organic swamp cranberry fruits (Vaccinium oxycoccus) were used in this research. The fruits were bought on the Polish market and stored at $4 \pm 1^{\circ} \mathrm{C}$ until processing. The cranberries were cut with a sharp knife in the geometric centre of the fruit to break hard skin and consequently to facilitate mass transfers during processes (Nowacka, Fijalkowska, et al., 2017). Fruits were subjected to ultrasound treatment and then to osmotic dehydration process.

\subsection{Sonication procedure (US)}

$50 \mathrm{~g}$ of samples were placed in a beaker into OD solutions in ratio of 1:4 (fruit:solution) (Fernandes, Gallão, \& Rodrigues, 2008; Tylewicz et al., 2011) in order to avoid changes in the solution concentration and then positioned in an ultrasonic bath MKD-3 (MKD Ultrasonics, Stary Konik, Poland, internal dimensions: $240 \times 140 \times 110 \mathrm{~mm})$. Sonication was conducted for $30 \mathrm{~min}$ (Nowacka, Fijalkowska, Wiktor, et al., 2018) using frequency $21 \mathrm{kHz}$ and the total power generated by sonotrodes $180 \mathrm{~W}$, that corresponded to an intensity of $3.6 \mathrm{~W} / \mathrm{g}$. During treatments the fruits were covered by a net in order to prevent them from flowing to the surface. During the sonication in OD solutions, significant temperature changes $\left( \pm 1^{\circ} \mathrm{C}\right)$ were not observed. The treatment was conducted in two repetitions for each osmotic solution. After the sonication, beakers were transferred to a rotary shaker with controlled temperature to continue the osmotic dehydration process.

\subsection{Osmotic dehydration (OD)}

Osmotic dehydration was carried out in three different solutions at the temperature of $40^{\circ} \mathrm{C}$ :

1. $61.5 \%$ sucrose solution (SA)

2. $30 \%$ sucrose solution with $0.1 \%$ of steviol glycosides (STV)

3. $40 \%$ trehalose solution $(\mathrm{T})$.

SA solution is usually used for osmotic dehydration as standard solution (Ciurzyńska, Kowalska, Czajkowska, \& Lenart, 2016). The solution of $30 \%$ of sucrose with addition of natural sweetener as steviol glycosides was used in order to reduce the sucrose content and keep similar sweetness. Steviol glycosides are up to 300 times sweeter than sucrose, thus the addition of $0.1 \%$ of steviol glycosides to a $30 \%$ sucrose solution provide a comparable sweetness to a $61.5 \%$ sucrose solution (Nowacka, Fijalkowska, et al., 2017). Trehalose solution was used as osmotic agent since it is able to improve the food structure and contribute to microbiological stability (Dermesonlouoglou, Zachariou, Andreou, \& Taoukis, 2016). Solutions were prepared by dissolving the solutes into distilled water. The sucrose (Pfeifer \& Langen Marketing Inc.) was used to prepare standard solutions. The steviol glycosides (Hortimex Plus Inc.) with purity of $95.48 \%$ (63.43\% of rebaudioside A, $22.85 \%$ of stevioside, $8.21 \%$ of rebaudioside C, $0.73 \%$ of dulcoside A and $0.26 \%$ of steviolbioside) and trehalose (Exacta + Optech Labcenter S.P.A) were used.

Due to high acidity of swamp cranberries, in order to obtain an acceptable taste of the product, the OD process was carried out till $72 \mathrm{~h}$ of immersing in osmotic solution (Nowacka, Fijalkowska, Dadan, et al., 2018). The samples subjected to OD process obtained a sweet-sour taste, which is characteristic for processed cranberry fruits available on the market as jams, sauces or dried fruits.

After the treatment, the cranberries were rinsed with distilled water for $10 \mathrm{~s}$ and dried with absorbent paper for $5 \mathrm{~s}$. The experiment was performed in duplicate for each solution. All examined samples are summarized in Table 1.

\subsection{Storage conditions}

After osmotic dehydration, samples were packed in microperforated plastic bags made from polylactid acid (PLA) and stored for 8 weeks in a climatic chamber at the temperature of $10^{\circ} \mathrm{C}$. The chosen quality properties were analysed immediately after OD treatment (T0) and after the first (T1), second (T2), fourth (T4) and eighth (T8) week of storage. For each storage time two bags for each sample were analysed.

\subsection{Analytical determinations}

\subsubsection{Mass transfer parameters}

The mass transfer after $72 \mathrm{~h}$ of OD process was evaluated in terms of weight reduction (WR, $\mathrm{kg} \cdot \mathrm{kg}^{-1}$ ), water loss ( $\mathrm{WL}, \mathrm{kg} \cdot \mathrm{kg}^{-1}$ ) and solid gain (SG, $\mathrm{kg} \cdot \mathrm{kg}^{-1}$ ) according to the following equations (Tylewicz et al., 2017): 
Table 1

Abbreviations of examined cranberry samples.

\begin{tabular}{|c|c|}
\hline Abbreviations & Sample description \\
\hline SA & cranberries subjected to osmotic dehydration with $61.5 \%$ sucrose solution \\
\hline STV & cranberries subjected to osmotic dehydration with $30 \%$ sucrose solution with addition $0.1 \%$ of steviol glycosides \\
\hline $\mathrm{T}$ & cranberries subjected to osmotic dehydration with $40 \%$ trehalose solution \\
\hline SA_US & cranberries subjected to 30 min ultrasound treatment and then osmotic dehydration with $61.5 \%$ sucrose solution \\
\hline STV_US & cranberries subjected to $30 \mathrm{~min}$ ultrasound treatment and then osmotic dehydration with $30 \%$ sucrose solution with addition $0.1 \%$ of steviol glycosides \\
\hline T_US & cranberries subjected to 30 min ultrasound treatment and then osmotic dehydration with $40 \%$ trehalose solution \\
\hline
\end{tabular}

$W R=\frac{m_{t}-m_{0}}{m_{0}}$

$W L=\frac{m_{t} x_{w t}-m_{0} x_{w 0}}{m_{0}}$

$S G=\frac{m_{t} x_{S T t}-m_{0} x_{S T 0}}{m_{0}}$

where:

$\mathrm{m}_{0}$ - initial weight before osmotic treatment $(\mathrm{kg})$

$\mathrm{m}_{\mathrm{t}}$ - weight after a time $\mathrm{t}(\mathrm{kg})$

$x_{w 0}-$ initial water mass fraction $\left(\mathrm{kg} \cdot \mathrm{kg}^{-1}\right)$

$x_{w t}$ - water mass fraction after a time $\mathrm{t}\left(\mathrm{kg} \cdot \mathrm{kg}^{-1}\right)$

$x_{S T 0}$ - initial total solids (dry matter) mass fraction $\left(\mathrm{kg} \cdot \mathrm{kg}^{-1}\right)$

$x_{S T t}$ - total solids (dry matter) mass fraction after a time $\mathrm{t}$ $\left(\mathrm{kg} \cdot \mathrm{kg}^{-1}\right)$

Moreover, weight reduction was also calculated for all the samples during the storage of 8 weeks, taking into account the weight of the samples at $\mathrm{T} 0$ and at each time of storage.

\subsubsection{Moisture content}

Moisture content was determined gravimetrically by drying the samples at $70^{\circ} \mathrm{C}$ until a constant weight was achieved (AOAC, 2002).

\subsubsection{Water activity}

Water activity $\left(a_{w}\right)$ was determined using the device AquaLab Series 3 TE (Decagon Devices Inc., Pullman, USA). The assay was performed in triplicate at room temperature $\left(23 \pm 1^{\circ} \mathrm{C}\right)$.

\subsubsection{Colour}

Colour was analysed using a spectro-photocolorimeter (HUNTERLAB Color-FlexTM, A60-1010-615, Reston, Virginia) equipped with a $12 \mathrm{~mm}$ diameter sample holder. The following parameters were used: illuminant D65 $(6500 \mathrm{~K})$, observer $10^{\circ}$. Before each series of measurements, the instrument was calibrated with a black and white tile $\left(L^{*}=93.47 ; a^{*}=-0.83 ; b^{*}=1.33\right)$. The colour data were expressed, according to the CIE L*a* $\mathrm{b}^{*}$ scale, in $\mathrm{L}^{*}$ (lightness), $\mathrm{a}^{*}$ (index of red) and $\mathrm{b}^{*}$ (index of yellow). The final values were calculated as an average of nine measures. Moreover, the hue angle $\left(\mathrm{h}^{\circ}\right)$ and the total colour differences $(\Delta \mathrm{E})$ were calculated with equations (4) and (5), respectively (Radojčin et al., 2015; Wiktor, Sledz, Nowacka, Rybak, \& Witrowa-Rajchert, 2016):

$h^{o}=\tan ^{-1} \frac{b^{*}}{a^{*}}$

$\Delta E=\sqrt{\left(\Delta L^{*}\right)^{2}+\left(\Delta a^{*}\right)^{2}+\left(\Delta b^{*}\right)^{2}}$

where:

$\Delta \mathrm{L}^{*}, \Delta \mathrm{a}^{*}, \Delta \mathrm{b}^{*}$ are the differences of mean $\mathrm{L}^{*}, \mathrm{a}^{*}$ and $\mathrm{b}^{*}$ parameters, respectively, between fresh cranberries and osmodehydrated untreated and US treated samples.

\subsubsection{Differential scanning calorimetry measurements (DSC)}

The calorimetric analysis was performed to determine the temperature of sugars' decomposition using a DSC Q20 model differential calorimeter (TA Instrument, Germany) according to Panarese, Tylewicz, Santagapita, Rocculi, and Dalla Rosa (2012). The DSC was equipped with a cooling unit (TA-Refrigetated Cooling System90). The calibration of temperature and melting enthalpies was carried out with distilled water $\left(\mathrm{T}_{\mathrm{m}} 0.0^{\circ} \mathrm{C}\right)$ and indium $\left(\mathrm{T}_{\mathrm{m}}\right.$ $156.60^{\circ} \mathrm{C}$ ). For the calibration and for sample measurements the same heating rate was used, under a $50 \mathrm{~mL} / \mathrm{min}$ dry nitrogen flow. About $20-30 \mathrm{mg}$ of each sample were weighed in $50 \mu \mathrm{l}$ aluminum capsules, closed and punctured just before the measurement. An empty capsule was used as a reference. The curves were obtained by heating the samples from 20 to $300^{\circ} \mathrm{C}$ at a rate of $10^{\circ} \mathrm{C} / \mathrm{min}$.

\subsubsection{Microbiology assessment}

The microbiological analyses were performed immediately after the osmotic treatment conducted for $72 \mathrm{~h}$ (T0) and during the storage period (after 1, 2, 4, 8 weeks). In particular, the cell loads of mesophilic aerobic bacteria, yeasts and moulds were monitored in all samples over the storage, according to the procedure reported by Mannozzi et al. (2018). The results are the average of three independent samples for each condition.

\subsection{Statistical analysis}

Analysis of variance (ANOVA) was performed using Statistical 7.0 Statsoft software (Tulsa, UK) using the Duncan test with a level of $\mathrm{p}<0.05$.

\section{Results and discussion}

\subsection{Mass transport balance during the OD treatment}

Table 2 shows the results of mass transfer parameters (weight reduction, water loss, solid gain) involved during the OD treatment for $72 \mathrm{~h}$ at $40^{\circ} \mathrm{C}$. From the table it is possible to observe that the

\section{Table 2}

Weight reduction $\left(\mathrm{kg} \cdot \mathrm{kg}^{-1}\right)$, water loss $\left(\mathrm{kg} \cdot \mathrm{kg}^{-1}\right)$, solid gain $\left(\mathrm{kg} \cdot \mathrm{kg}^{-1}\right)$ of osmodehydrated cranberries with or without US pre-treatment after $72 \mathrm{~h}$ of osmotic dehydration in sucrose (SA) sucrose + steviol glycoside (STV) and trehalose (T) solutions.

\begin{tabular}{llll}
\hline Samples & Weight reduction & Water loss & Solid gain \\
\hline SA & $0.402 \pm 0.002^{\mathrm{b}}$ & $0.586 \pm 0.002^{\mathrm{b}}$ & $0.184 \pm 0.002^{\mathrm{a}}$ \\
STV & $0.234 \pm 0.001^{\mathrm{d}}$ & $0.332 \pm 0.001^{\mathrm{e}}$ & $0.098 \pm 0.001^{\mathrm{c}}$ \\
T & $0.172 \pm 0.001^{\mathrm{f}}$ & $0.328 \pm 0.001^{\mathrm{f}}$ & $0.156 \pm 0.001^{\mathrm{b}}$ \\
SA_US & $0.424 \pm 0.002^{\mathrm{a}}$ & $0.605 \pm 0.002^{\mathrm{a}}$ & $0.182 \pm 0.002^{\mathrm{a}}$ \\
STV_US & $0.299 \pm 0.001^{\mathrm{c}}$ & $0.381 \pm 0.001^{\mathrm{c}}$ & $0.081 \pm 0.001^{\mathrm{d}}$ \\
T_US & $0.189 \pm 0.001^{\mathrm{e}}$ & $0.345 \pm 0.001^{\mathrm{d}}$ & $0.156 \pm 0.001^{\mathrm{b}}$ \\
\hline
\end{tabular}

Different letters within the same column indicate statistical differences $(p<0.05)$. 
highest weight reduction was observed for samples treated with sucrose (SA), followed by samples treated with sucrose in combination with steviol glycoside (STV) and samples dehydrated with trehalose $(T)$. These differences were similar to the ones observed for the water loss from the samples. In fact, the highest water loss was observed for samples treated with high concentration of sucrose. This is due to the difference in osmotic pressure between food matrix and osmotic solution. SA solution presented the higher concentration of sugar (61.5\%) and was characterized by the lowest $\mathrm{a}_{\mathrm{w}}$ of about 0.867 , while the solutions of STV and T presented the values of 0.976 and 0.965 , respectively.

In a study investigating the dehydration of apples, when sucrose and trehalose were used as osmotic solution at the same $\mathrm{a}_{\mathrm{w}}(0.96)$ lower water mass fraction $\left(0.819 \mathrm{~g} \cdot \mathrm{g}^{-1}\right)$ was observed in samples dehydrated with sucrose solution against $0.838 \mathrm{~g} \cdot \mathrm{g}^{-1}$ observed for trehalose solution, indicating the lower dewatering for the latest samples (Atarés, Chiralt, Corradini, \& González-Martínez, 2009). Also Tylewicz et al. (2017) observed that samples treated with trehalose solution at the same concentration as sucrose $(40 \% \mathrm{w} / \mathrm{w})$ were characterized by a lower final dehydration level (at $120 \mathrm{~min}$ of OD) even if a higher initial rate of dehydration was observed.

As explained by Galmarini, Baeza, Sanchez, Zamora, and Chirife (2011) at the same solute concentration, the $\mathrm{a}_{\mathrm{w}}$ (which explains the engine of transport) is lower in sucrose solution as well as its viscosity (which explains the molcular diffusion). Therefore, the water transport is faster in samples dehydrated in sucrose than these dehydrated with trehalose.

Concerning the solid gain, the highest value was observed in samples treated with sucrose, followed by the samples treated with trehalose. Trehalose was found to have a higher effect on solid gain when used at the same concentration as sucrose (Tylewicz et al., 2017). In the present study, while a slightly but significantly higher water loss was observed for STV samples compared to T samples, the latter showed almost twice the solid gain.

Ultrasound pre-treatment led to a significant increase of weight reduction and water loss in all the samples. It is well known that ultrasound create microscopic channels which may ease moisture removal and increase the diffusivity of the water (Fernandes, Gallão, et al., 2008; Fernandes \& Rodrigues, 2007; Nowacka, Śledź, et al., 2014). On the other side, for SA_US and T_US samples the US pre-treatment did not promote any differences for solid gain, while it caused a significant decrease in samples STV_US. This is probably because the solid gain comprises both soluble and insoluble solids (fruit matrix), and therefore any lysis effect in the tissue is accounted in this group.

\subsection{Weight reduction and dry matter content during storage}

Weight reduction and dry matter content of osmodehydrated cranberries throughout storage are shown respectively in Figs. 1 and 2 . Weight loss was generally in the range of $2-5 \%$. The US pre-treatment led to a significantly lower weight loss in samples treated with SA and STV in comparison to the samples only osmodehydrated. The samples treated with sucrose solution both with or without US application presented the lowest weight loss, followed by samples treated by trehalose and then the samples treated with sucrose and steviol glycoside, which presented the highest weight loss. In general, the loss of weight during storage could be due to the water loss that resulted from surface water evaporation, and also by gravity mechanism that moves the liquid phase to the bottom of samples, leaving the tissue. Moreover, respiration and transpiration as well as the wounding stress during the processing of the fruits could cause the higher weight gain during the storage (Ferrari, Sarantópoulos, Carmello-Guerreiro, \& Hubinger, 2013). In fact, in the case of our study the weight loss was

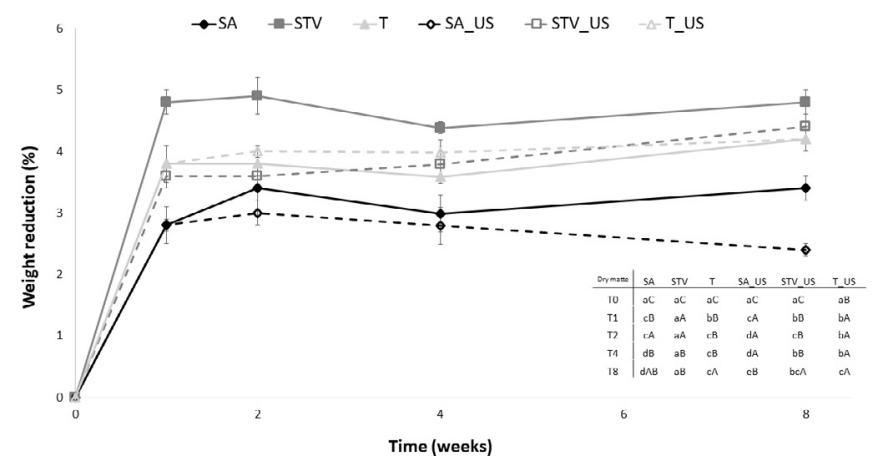

Fig. 1. Weight reduction of osmodehydrated cranberries with or without US pretreatment during storage at $10^{\circ} \mathrm{C}$. Different letters indicate statistical differences $(p<0.05)$ (lowercase letter within the same row indicate differences among different treatments for the same storage time, while capital letters within the same column indicate differences among different storage times for the same treatment).

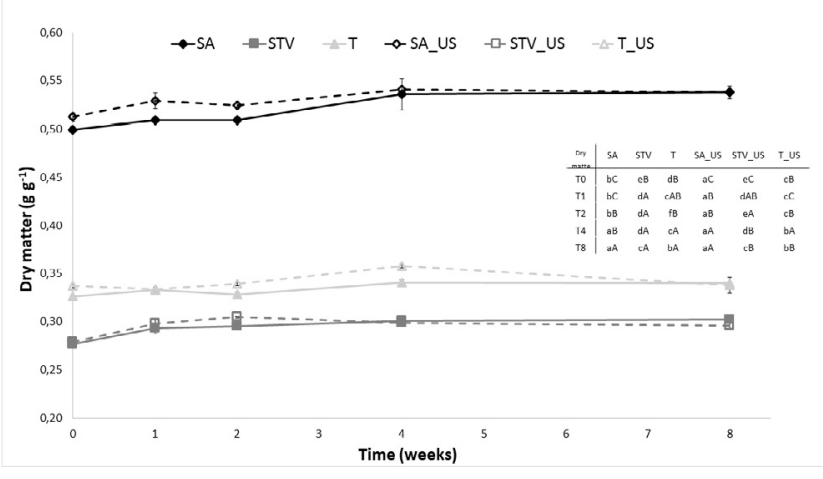

Fig. 2. Dry matter content $\left(\mathrm{g} \cdot \mathrm{g}^{-1}\right)$ of osmodehydrated cranberries with or without US pre-treatment during storage at $10^{\circ} \mathrm{C}$. Different letters indicate statistical differences $(p<0.05)$ (lowercase letter within the same row indicate differences among different treatments for the same storage time, while capital letters within the same column indicate differences among different storage times for the same treatment).

the highest in samples dehydrated with STV, which probably could still maintain the biological capacity to the cell respiration or even to ferment. Due to the higher dehydration during the process, samples treated with sucrose presented also the lower water content (Fig. 2) compared to the other samples, that could be the reason for the lower loss of water during the storage.

As shown in Fig. 2, the highest value of dry matter was observed for cranberries samples treated at $61.5 \%$ sucrose solution (around $0.5 \mathrm{~g} \cdot \mathrm{g}^{-1}$ ). As already observed for mass transfer parameters, these samples were subjected to a higher dewatering and thus higher increase of the dry mater. During storage, a further (even if only slight) increase of dry mater was observed in all samples. Higher dry matter observed in SA_US and STV_US treated samples, in comparison to their controls, immediately after the treatment and at different period of storage was probably due to the partial destruction of the fruit peel allowing a higher penetration of sucrose into the tissue (Nowacka, Fijalkowska, et al., 2017).

\subsection{Water activity}

Fig. 3 shows the water activity evolution for osmodehydrated cranberry samples with or without US pre-treatment during storage. The samples treated with SA presented the lowest $a_{w}$ in comparison to the samples dehydrated with other solutions, because of the higher osmotic potential differences. The application 


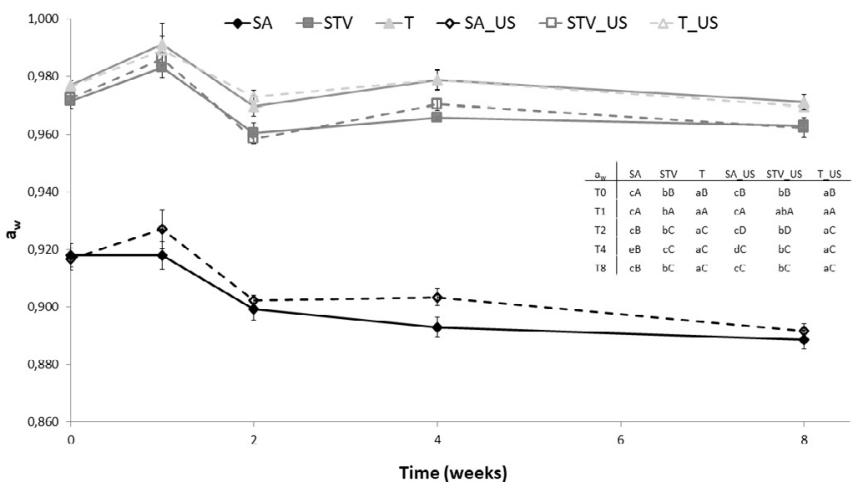

Fig. 3. Water activity of osmodehydrated cranberries with or without US pretreatment during storage at $10^{\circ} \mathrm{C}$. Different letters indicate statistical differences $(p<0.05)$ (lowercase letter within the same row indicate differences among different treatments for the same storage time, while capital letters within the same column indicate differences among different storage times for the same treatment).

of US did not change significantly the water activity of the samples at T0. Also, Stojanovic and Silva (2006) and Nowacka, Tylewicz, et al. (2017) did not observed differences in water activity of ultrasound osmodehydrated blueberry and kiwifruit samples. An increase of water activity was observed at T1, while during further storage a slight but progressive decrease of water activity was noticed. The results are in accordance with the dry matter content, in fact the increase of solutes content during storage could lead to the decrease of water activity.

\subsection{Colour changes during storage}

Table 3 shows the changes of colour parameters of lightness $\left(L^{*}\right)$, red index $\left(a^{*}\right)$, yellow index $\left(b^{*}\right)$, hue angle $\left(h^{\circ}\right)$ and total colour differences $(\Delta E)$. During storage, until the fourth week a decrease of the $L^{*}$ parameter was observed for all samples. Cranberries dehydrated with ultrasound in trehalose solution (T_US) showed the lowest lightness value. Obtained data are in agreement with those reported in the literature, according to which the osmotic treatment leads to a decrease of the initial $\mathrm{L}^{*}$ values. This phenomenon can be related to the modification of the surface layer of the product due to immersion in sugary solutions. This effect was noticed by Prinzivalli, Brambilla, Maffi, Lo Scalzo, and Torreggiani (2006) in strawberry slices. As reported in the literature in the case of dehydrated apples and carrots, the pre-treatment with ultrasound leads to an increase in lightness $\left(\mathrm{L}^{*}\right)$ compared to the untreated fruit (Fijalkowska, Nowacka, Wiktor, Sledz, \& Witrowa-Rajchert, 2016). In our case, significantly higher values of $L^{*}$ for untreated and US treated samples were observed only at the 8th week of storage. Probably these colour changes were associated with loss of the anthocyanins during storage, which are responsible for red colour of cranberry fruits (Nowacka, Fijalkowska, Dadan, et al., 2018; Oszmiański, Wojdyło, Lachowicz, Gorzelany, \& Matłok, 2016). This was also confirmed by the changes of a* parameter, which represent the red colour. In general, a decrease of $a^{*}$ and $b^{*}$ parameters was noted during storage, while the hue angle values, in the range of $16-28$, indicating a red hue of the samples, did not show a real trend. In fact, they first decreased after one week and then started to increase till the fourth week, and then again decreased at eight week of storage.

In order to evaluate the colour alteration, the total colour differences was calculated. Generally, the value of $\Delta \mathrm{E}$ higher than 2 is considered as a visible difference between the samples (Fijalkowska, Nowacka, \& Witrowa-Rajchert, 2017). All samples were characterized by high values of $\Delta \mathrm{E}$ in the range from 6 to 10
Table 3

Colour parameters $L^{*}, a^{*}, b^{*}$, hue angle $h^{\circ}$ and total colour differences $(\Delta E)$ of osmodehydrated cranberries with or without US pre-treatment during storage at $10{ }^{\circ} \mathrm{C}$.

\begin{tabular}{|c|c|c|c|c|c|}
\hline \multicolumn{6}{|c|}{$\mathrm{L}^{*}$} \\
\hline & T0 & $\mathrm{T} 1$ & $\mathrm{~T} 2$ & $\mathrm{~T} 4$ & $\mathrm{~T} 8$ \\
\hline $\begin{array}{l}\text { SA } \\
\text { STV } \\
\text { T } \\
\text { SA_US } \\
\text { STV_US } \\
\text { T_US }\end{array}$ & $\begin{array}{l}21 \pm 3^{\mathrm{aA}} \\
17 \pm 1^{\mathrm{bB}} \\
18 \pm 2^{\mathrm{abB}} \\
20 \pm 3^{\mathrm{abB}} \\
18 \pm 2^{\mathrm{abB}} \\
19 \pm 2^{\mathrm{abB}}\end{array}$ & $\begin{array}{l}17 \pm 1^{\mathrm{aAB}} \\
16.6 \pm 0.4^{\mathrm{aB}} \\
18 \pm 2^{\mathrm{aAB}} \\
18 \pm 1^{\mathrm{aB}} \\
17 \pm 1^{\mathrm{aB}} \\
19 \pm 1^{\mathrm{aBC}}\end{array}$ & $\begin{array}{l}17 \pm 1^{\mathrm{aAB}} \\
15 \pm 1^{\mathrm{aB}} \\
15 \pm 3^{\mathrm{aB}} \\
17 \pm 2^{\mathrm{aB}} \\
19 \pm 3^{\mathrm{aAB}} \\
15 \pm 2^{\mathrm{aC}}\end{array}$ & $\begin{array}{l}15 \pm 1^{\mathrm{abB}} \\
15 \pm 2^{\mathrm{abB}} \\
13 \pm 3^{\mathrm{abB}} \\
16 \pm 2^{\mathrm{aB}} \\
14 \pm 3^{\mathrm{abB}} \\
10.2 \pm 0.5^{\mathrm{bD}}\end{array}$ & $\begin{array}{l}24 \pm 3^{\mathrm{abA}} \\
21.8 \pm 0.1^{\mathrm{bA}} \\
22 \pm 1^{\mathrm{abA}} \\
25 \pm 1^{\mathrm{aA}} \\
22.2 \pm 0.3^{\mathrm{abA}} \\
23 \pm 1^{\mathrm{abA}}\end{array}$ \\
\hline \multicolumn{6}{|c|}{$a^{*}$} \\
\hline & T0 & $\mathrm{T} 1$ & $\mathrm{~T} 2$ & $\mathrm{~T} 4$ & T8 \\
\hline $\begin{array}{l}\text { SA } \\
\text { STV } \\
\text { T } \\
\text { SA_US } \\
\text { STV_US } \\
\text { T_US }\end{array}$ & $\begin{array}{l}26 \pm 2^{\mathrm{aA}} \\
25 \pm 2^{\mathrm{abA}} \\
25 \pm 2^{\mathrm{abAB}} \\
24 \pm 1^{\mathrm{abB}} \\
23 \pm 2^{\mathrm{bA}} \\
25 \pm 2^{\mathrm{abA}}\end{array}$ & $\begin{array}{l}24 \pm 1^{\mathrm{aA}} \\
21 \pm 1^{\mathrm{aBC}} \\
21 \pm 3^{\mathrm{aBC}} \\
22 \pm 2^{\mathrm{aB}} \\
21 \pm 2^{\mathrm{aA}} \\
23 \pm 2^{\mathrm{aAB}}\end{array}$ & $\begin{array}{l}24 \pm 2^{\mathrm{aA}} \\
22 \pm 2^{\mathrm{aAB}} \\
23 \pm 3^{\mathrm{aABC}} \\
25 \pm 2^{\mathrm{aAB}} \\
22 \pm 2^{\mathrm{aA}} \\
20 \pm 1^{\mathrm{aB}}\end{array}$ & $\begin{array}{l}28 \pm 3^{\mathrm{aA}} \\
24 \pm 2^{\mathrm{aAB}} \\
27 \pm 2^{\mathrm{aA}} \\
29 \pm 2^{\mathrm{aA}} \\
25 \pm 3^{\mathrm{aA}} \\
28 \pm 1^{\mathrm{aA}}\end{array}$ & $\begin{array}{l}18 \pm 1^{\mathrm{abB}} \\
17.6 \pm 0.1^{\mathrm{abC}} \\
19 \pm 2^{\mathrm{ac}} \\
18 \pm 1^{\mathrm{abC}} \\
15 \pm 1^{\mathrm{bcB}} \\
14 \pm 1^{\mathrm{cC}}\end{array}$ \\
\hline \multicolumn{6}{|c|}{$\mathrm{b}^{*}$} \\
\hline & T0 & $\mathrm{T} 1$ & $\mathrm{~T} 2$ & $\mathrm{~T} 4$ & T8 \\
\hline $\begin{array}{l}\text { SA } \\
\text { STV } \\
\text { T } \\
\text { SA_US } \\
\text { STV_US } \\
\text { T_US }\end{array}$ & $\begin{array}{l}12 \pm 1^{\mathrm{aB}} \\
10 \pm 1^{\mathrm{abAB}} \\
11 \pm 2^{\mathrm{abAB}} \\
11 \pm 1^{\mathrm{abB}} \\
9 \pm 2^{\mathrm{bAB}} \\
10 \pm 3^{\mathrm{abA}}\end{array}$ & $\begin{array}{l}10 \pm 1 \mathrm{aAB} \\
6 \pm 1 \mathrm{bC} \\
6 \pm 2 \mathrm{bC} \\
9 \pm 1 \mathrm{abBC} \\
8 \pm 1 \mathrm{abAB} \\
9 \pm 1 \mathrm{abAB}\end{array}$ & $\begin{array}{l}10 \pm 2 \mathrm{aAB} \\
8 \pm 4 \text { aABC } \\
8 \pm 1 \text { aBC } \\
11 \pm 1 \mathrm{aBC} \\
8 \pm 2 \mathrm{aAB} \\
8 \pm 1 \mathrm{aAB}\end{array}$ & $\begin{array}{l}15 \pm 2^{\mathrm{aA}} \\
11 \pm 4^{\mathrm{aA}} \\
13 \pm 1^{\mathrm{aA}} \\
15 \pm 1^{\mathrm{aA}} \\
12 \pm 2^{\mathrm{aA}} \\
12 \pm 2^{\mathrm{aA}}\end{array}$ & $\begin{array}{l}8.3 \pm 1 \mathrm{abC} \\
6.4 \pm 0.4 \mathrm{bcdBC} \\
7 \pm 1 \mathrm{abcBC} \\
9 \pm 1 \mathrm{aC} \\
5 \pm 1 \mathrm{cdB} \\
4.6 \pm 0.2^{\mathrm{dB}}\end{array}$ \\
\hline \multicolumn{6}{|c|}{$\mathrm{h}^{\circ}$} \\
\hline & T0 & $\mathrm{T} 1$ & $\mathrm{~T} 2$ & $\mathrm{~T} 4$ & T8 \\
\hline $\begin{array}{l}\text { SA } \\
\text { STV } \\
\text { T } \\
\text { SA_US } \\
\text { STV_US } \\
\text { T_US }\end{array}$ & $\begin{array}{l}25 \pm 2^{\mathrm{aB}} \\
21 \pm 2^{\mathrm{abAB}} \\
23 \pm 3^{\mathrm{abA}} \\
25 \pm 2^{\mathrm{bAB}} \\
21 \pm 3^{\mathrm{abA}} \\
21 \pm 3^{\mathrm{bA}}\end{array}$ & $\begin{array}{l}23 \pm 1^{a B} \\
16 \pm 2^{a B} \\
17 \pm 5^{a B} \\
22 \pm 2^{a B} \\
21 \pm 2^{a A} \\
21 \pm 2^{a A}\end{array}$ & $\begin{array}{l}23 \pm 1^{\mathrm{aB}} \\
19 \pm 1^{\mathrm{aAB}} \\
18 \pm 2^{\mathrm{aAB}} \\
23 \pm 3^{\mathrm{aAB}} \\
20 \pm 4^{\mathrm{aA}} \\
21 \pm 1^{\mathrm{aA}}\end{array}$ & $\begin{array}{l}28 \pm 2^{\mathrm{aA}} \\
23 \pm 6^{\mathrm{aA}} \\
25 \pm 2^{\mathrm{aA}} \\
27.9 \pm 0.3^{\mathrm{aA}} \\
24 \pm 2^{\mathrm{aA}} \\
24 \pm 3^{\mathrm{aA}}\end{array}$ & $\begin{array}{l}24 \pm 2^{\mathrm{abAB}} \\
20 \pm 1 \mathrm{cdAB} \\
21.6 \pm 0.1^{\mathrm{bcAB}} \\
25 \pm 1 \mathrm{aAB} \\
19 \pm 1^{\mathrm{cdA}} \\
18 \pm 1 \mathrm{dA}\end{array}$ \\
\hline \multicolumn{6}{|c|}{$\Delta \mathrm{E}$} \\
\hline & T0 & $\mathrm{T} 1$ & $\mathrm{~T} 2$ & $\mathrm{~T} 4$ & T8 \\
\hline $\begin{array}{l}\text { SA } \\
\text { STV } \\
T \\
\text { SA_US } \\
\text { STV_US } \\
\text { T_US }\end{array}$ & $\begin{array}{l}6 \pm 2^{\mathrm{bC}} \\
8 \pm 2^{\mathrm{abC}} \\
8 \pm 3^{\mathrm{abC}} \\
8 \pm 1^{\mathrm{abC}} \\
10 \pm 3^{\mathrm{aB}} \\
8 \pm 2^{\mathrm{abC}}\end{array}$ & $\begin{array}{l}8 \pm 1 \mathrm{bC} \\
13 \pm 2^{\mathrm{aB}} \\
13 \pm 2^{\mathrm{aB}} \\
10 \pm 2^{\mathrm{abC}} \\
11 \pm 2^{\mathrm{abB}} \\
9 \pm 1^{\mathrm{abC}}\end{array}$ & $\begin{array}{l}8 \pm 2^{\mathrm{aC}} \\
11 \pm 2^{a B} \\
11 \pm 2^{a B C} \\
7 \pm 3^{a C} \\
11 \pm 3^{a B} \\
13 \pm 2^{a B}\end{array}$ & $\begin{array}{l}21.3 \pm 0.3^{\mathrm{aA}} \\
22.0 \pm 0.6^{\mathrm{aA}} \\
21.0 \pm 0.4^{\mathrm{aA}} \\
21.1 \pm 0.1^{\mathrm{aA}} \\
21 \pm 1^{\mathrm{aA}} \\
21.0 \pm 0.2^{\mathrm{aA}}\end{array}$ & $\begin{array}{l}14 \pm 1^{\mathrm{cB}} \\
14.9 \pm 0.2^{\mathrm{bcB}} \\
14 \pm 2^{\mathrm{cB}} \\
14 \pm 1^{\mathrm{bcB}} \\
17 \pm 2^{\mathrm{abA}} \\
19 \pm 1^{\mathrm{aA}}\end{array}$ \\
\hline
\end{tabular}

Different letters indicate statistical differences $(p<0.05)$ for each colour parameter (lowercase letter within the same column indicate differences among different treatments for the same storage time, while capital letters within the same row indicate differences among different storage times for the same treatment).

after the osmotic dehydration process and the total colour differences grow during storage till 4th week. In the 8th week of storage the decrease of $\Delta \mathrm{E}$ was observed. The changes of colour are usually connected with the chemical compounds, which are responsible for the colour e.g. anthocyanins (Nowacka, Fijalkowska, Dadan, et al., 2018). In particular, red colour is one of the main indicators by which the consumer can assesses the quality of fresh cranberries. It makes the product more or less attractive and it is the first characteristic that the consumer perceives (Kutyła-Olesiuk, Nowacka, Wesoły, \& Ciosek, 2013; Nowacka, Fijalkowska, Dadan, et al., 2018). The reduction of the red component of colour might be connected with the solubilization of pigments in the solution during osmotic treatment and the degradation of anthocyanins. Anthocyanins are particularly sensitive to osmotic dehydration, which may be the reason for the general reduction in colour (de Bruijn \& Bórquez, 2014). 


\subsection{Thermal analysis DSC results}

DSC measurements were performed to evaluate the melting of sugars introduced by OD in the samples and to evaluate any differences during storage. The melting temperature $\left(\mathrm{Tm},{ }^{\circ} \mathrm{C}\right)$ and

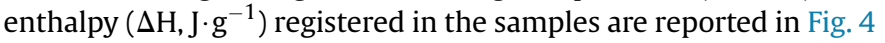
and Fig. 5, respectively.

Melting of sucrose is known to occur in the temperature range of 206-232 ${ }^{\circ} \mathrm{C}$ (Abd-Elrahman \& Ahmed, 2009; Panarese et al., 2012). In the present study, after the OD treatment a melting temperature of $211^{\circ} \mathrm{C}$ was found, which is consistent with literature data previously reported.

The presence of steviol glycosides at $0.1 \%$ did not influence the melting temperature of the solution. In the case of trehalose, a melting peak with a temperature of $246^{\circ} \mathrm{C}$ was observed. While about the crystallization of trehalose and its influence on glass transition there is a wide literature, its melting behaviour is not often studied. Raemy and Schweizer (1983) studied the melting properties of different sugars and indicated a melting temperature for trehalose of $235^{\circ} \mathrm{C}$, higher compared to sucrose one $\left(215^{\circ} \mathrm{C}\right)$, which is similar to what we found in the present study.

No differences were observed during storage in the peaks of melting temperatures for all the samples.

The enthalpy values were found to be proportional to the sugar contents. The initial values reported in Fig. 5, of about 40, 27 and $19 \mathrm{~J} \cdot \mathrm{g}^{-1}$ respectively for SA, T and STV samples, reflect the impregnation levels reported in Table 2 for samples after $72 \mathrm{~h}$ of OD process. While for STV sample, no differences were observed when US was applied, for SA and T samples, an increase in the melting enthalpy was noticed. This difference may be attributed to the differences in mass transfer as shown in Table 2. Indeed, while water loss increased in STV sample after US application (increase of $8 \%$, compared to 2 and $6 \%$ of respectively SA and T samples), solid gain decreased for of about $1.7 \%$. Moreover, it could be possible that T and T_US samples suffer partial hydrolyzation of trehalose.

\subsection{Microbial analysis}

In Table 4 the results of total mesophilic aerobic bacteria and yeasts in cranberries samples during the shelf-life are reported. Osmotic dehydration improves the microbiological shelf-life since it leads to a reduction in water activity (Castelló, Igual, Fito, \& Chiralt, 2009). In fact, even in our case study, the samples that reached lower water activity (SA; SA_US30) showed a better

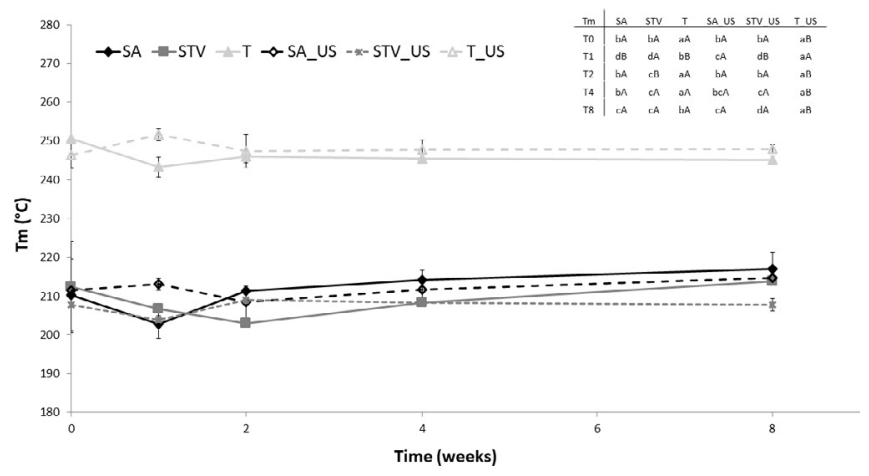

Fig. 4. The melting temperature $\left(\mathrm{Tm},{ }^{\circ} \mathrm{C}\right)$ of osmodehydrated cranberries with or without US pre-treatment during storage at $10^{\circ} \mathrm{C}$. Different letters indicate statistical differences $(p<0.05)$ (lowercase letter within the same row indicate differences among different treatments for the same storage time, while capital letters within the same column indicate differences among different storage times for the same treatment).

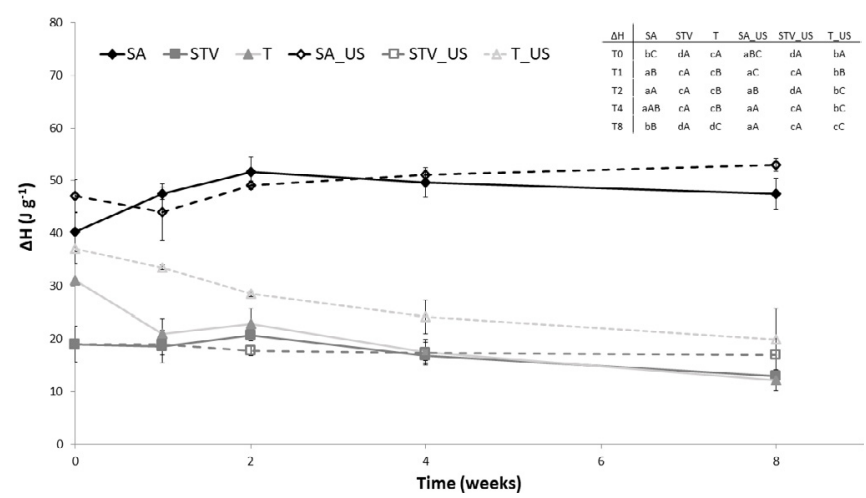

Fig. 5. Melting enthalpy $\left(\Delta \mathrm{H}, \mathrm{J} \cdot \mathrm{g}^{-1}\right)$ of osmodehydrated cranberries with or without US pre-treatment during storage at $10^{\circ} \mathrm{C}$. Different letters indicate statistical differences $(p<0.05)$ (lowercase letter within the same row indicate differences among different treatments for the same storage time, while capital letters within the same column indicate differences among different storage times for the same treatment).

Table 4

Mesophilic aerobic bacteria and yeast of osmodehydrated cranberries with or without US pre-treatment during storage at $10^{\circ} \mathrm{C}$.

\begin{tabular}{|c|c|c|c|c|c|}
\hline & \multicolumn{5}{|c|}{ Mesophilic aerobic bacteria $\log$ CFU/g } \\
\hline & T0 & $\mathrm{T} 1$ & $\mathrm{~T} 2$ & $\mathrm{~T} 4$ & $\mathrm{~T} 8$ \\
\hline SA & $2.2 \pm 0.2^{\mathrm{a}}$ & $3.3 \pm 0.3^{b}$ & $2.9 \pm 0.2^{\mathrm{d}}$ & $2.9 \pm 0.3^{c}$ & $4.9 \pm 0.2$ \\
\hline STV & $2.4 \pm 0.2^{\mathrm{a}}$ & $3.8 \pm 0.2^{\mathrm{b}}$ & $5.4 \pm 0.3^{c}$ & $7.9 \pm 0.2^{\mathrm{a}}$ & $8.0 \pm 0.3^{3}$ \\
\hline $\mathrm{T}$ & $2.0 \pm 0.3^{\mathrm{a}}$ & $4.8 \pm 0.2^{\mathrm{a}}$ & $6.0 \pm 0.2^{\mathrm{b}}$ & $7.2 \pm 0.2^{\mathrm{b}}$ & $8.2 \pm 0.2$ \\
\hline SA_US & $2.5 \pm 0.3^{\mathrm{a}}$ & $1.5 \pm 0.3^{c}$ & $2.8 \pm 0.2^{\mathrm{d}}$ & $2.9 \pm 0.2^{c}$ & $5.5 \pm 0.2^{1}$ \\
\hline STV_US & $2.0 \pm 0.3^{\mathrm{a}}$ & $5.1 \pm 0.2^{\mathrm{a}}$ & $6.7 \pm 0.1^{\mathrm{a}}$ & $7.9 \pm 0.3^{\mathrm{a}}$ & $8.6 \pm 0.4$ \\
\hline \multirow[t]{3}{*}{ T_US } & $2.5 \pm 0.2^{\mathrm{a}}$ & $5.2 \pm 0.3^{\mathrm{a}}$ & $7.0 \pm 0.3^{\mathrm{a}}$ & $7.4 \pm 0.3^{\mathrm{ab}}$ & $8.4 \pm 0.3^{3}$ \\
\hline & \multicolumn{5}{|c|}{ Yeast log CFU/g } \\
\hline & T0 & $\mathrm{T} 1$ & $\mathrm{~T} 2$ & $\mathrm{~T} 4$ & $\mathrm{~T} 8$ \\
\hline SA & $2.6 \pm 0.2^{\mathrm{a}}$ & $1.5 \pm 0.2^{c}$ & $2.7 \pm 0.12^{\mathrm{d}}$ & $1.9 \pm 0.5^{c}$ & $4.9 \pm 0.2^{1}$ \\
\hline STV & $2.7 \pm 0.2^{\mathrm{a}}$ & $3.1 \pm 0.2^{\mathrm{b}}$ & $5.3 \pm 0.2^{c}$ & $7.9 \pm 0.3^{\mathrm{a}}$ & $8.3 \pm 0.3^{2}$ \\
\hline $\mathrm{T}$ & $1.9 \pm 0.2^{c}$ & $4.6 \pm 0.3^{a}$ & $6.1 \pm 0.2^{b}$ & $7.1 \pm 0.2^{\mathrm{b}}$ & $8.1 \pm 0.4$ \\
\hline SA_US & $2.1 \pm 0.2^{\mathrm{bc}}$ & $1.0 \pm 0.4^{\mathrm{c}}$ & $2.1 \pm 0.2^{\mathrm{e}}$ & $2.8 \pm 0.3^{c}$ & $5.2 \pm 0.2$ \\
\hline STV_US & $1.9 \pm 0.2^{c}$ & $4.6 \pm 0.3^{a}$ & $6.6 \pm 0.2^{\mathrm{a}}$ & $7.8 \pm 0.3^{\mathrm{a}}$ & $8.2 \pm 0.3$ \\
\hline T_US & $2.5 \pm 0.2^{\mathrm{ab}}$ & $5.2 \pm 0.3^{\mathrm{a}}$ & $6.8 \pm 0.3^{\mathrm{a}}$ & $7.3 \pm 0.3^{\mathrm{ab}}$ & $8.3 \pm 0.3$ \\
\hline
\end{tabular}

Different letters within the same column indicate statistical differences $(p<0.05)$.

microbiological shelf-life over time. This is probably because of the high osmotic pressure of the SA solution which can enable longer shelf-life. Moreover, sucrose absorption has promoted an increase in the viscosity of the liquid phase, influencing the kinetics of the microbial growth, as reported in the case of kiwifruit by (Gianotti, Sacchetti, Guerzoni, \& Dalla Rosa, 2001). According to the recommended microbiological criteria for fruits and vegetables, the maximum limits for the total mesophilic aerobic bacteria and yeasts/moulds are set to be $1 \times 10^{4} \mathrm{CFU} / \mathrm{g}$ and $1 \times 10^{2} \mathrm{CFU} / \mathrm{g}$, respectively (Anderson and Calderón, 1999). As reported in Table 4, there were no significant differences between the samples pretreated or not with ultrasound. However, the cell load of the total mesophilic aerobic bacteria, exceeded the maximum levels recommended by Anderson and Calderón (1999), after the first week of storage for the samples osmodehydrated in solutions with $30 \%$ sucrose $+0.1 \%$ stevia and $40 \%$ trehalose that were subjected to ultrasound pre-treatment. During the second week of storage this microbiological limit was also exceeded for samples osmodehydrated with sucrose + stevia and trehalose and not subjected to ultrasound pre-treatment, whereas for samples osmodehydrated with $61.5 \%$ of sucrose solution, with and without US pre-treatment, this limit was only exceeded after eighth weeks of storage. As regard to yeasts, the recommended cell load was superseded by all 
the samples at the beginning of the first week of storage, whereas for moulds the cell load exceeds only for samples osmodehydrated with trehalose. During the fourth week of storage, the recommended cell load for moulds $1 \times 10^{2} \mathrm{CFU} / \mathrm{g}$ was superseded by all samples with the exception of those osmodehydrated with $61.5 \%$ sucrose that exceeded this limit only during the eighth week (data not shown) of storage. In fruits and vegetables, intercellular spaces play an important role in the penetration of microorganisms. In general, bacteria, yeast or mould cells are much smaller than plant cells, thus they can easily penetrate into the vegetable tissues (Alzamora et al., 2005).

\section{Conclusions}

The mass transfer parameters during OD treatment were significantly influenced by ultrasound application and the type of osmotic solution used. The highest water loss was observed in samples treated with sucrose and ultrasound (SA_US). During storage, ultrasound pre-treatment led to lower weight reduction in cranberry samples treated with any type of the solution in comparison to those without US pre-treatment. Moreover, during storage, the US pre-treatment promoted changes in the qualitative characteristics, in particular of colour leading to a higher lightness $\left(\mathrm{L}^{*}\right)$ in comparison to the untreated fruit. The thermal analysis allowed the identification of the variations in melting temperatures and enthalpies as a result of osmotic treatment and storage.

The sample that preserved the best chemico-physical and microbiological characteristics during storage was the one treated with $61.5 \%$ sucrose solution, due to the lowest water activity. However, further studies are necessary in order to better understand the chemico-physical and physiological mechanisms underlying the highlighted changes.

\section{Acknowledgements}

Financial support for this project is provided by funding bodies within the FP7 ERA-Net CORE Organic Plus, and with cofounds from the European Commission (No 618107).

\section{References}

Abd-Elrahman, M. I., \& Ahmed, S. M. (2009). Thermal degradation kinetics and geometrical stability of D-sucrose. International Journal of Polymeric Materials, 58(6), 322-335. https://doi.org/10.1080/00914030902859273.

Alzamora, S. M., Salvatori, D., Tapia, M. S., López-Malo, A., Welti-Chanes, J., \& Fito, P. (2005). Novel functional foods from vegetable matrices impregnated with biologically active compounds. Journal of Food Engineering, 67(1-2), 205-214. https://doi.org/10.1016/j.jfoodeng.2004.05.067.

Anderson, M. D. R. P., \& Calderón, V. (1999). Microbiología alimentaria: Metodología analítica para alimentos y bebidas. Ediciones Diaz de Santos.

AOAC International. (2002). In Official methods of analysis of AOAC international (17th ed.) 920.15.

Atarés, L., Chiralt, A., Corradini, M. G., \& González-Martínez, C. (2009). Effect of the solute on the development of compositional profiles in osmotic dehydrated apple slices. LWT - Food Science and Technology, 42(1), 412-417. https://doi.org/ 10.1016/j.lwt.2008.03.009.

Blumberg, J. B., Camesano, T. A., Cassidy, A., Kris-etherton, P., Howell, A., Manach, C., et al. (2013). Cranberries and their bioactive constituents. Advances in Nutrition, 4, 618-632. https://doi.org/10.3945/an.113.004473.618.

de Bruijn, J., \& Bórquez, R. (2014). Quality retention in strawberries dried by emerging dehydration methods. Food Research International, 63, 42-48. https:// doi.org/10.1016/j.foodres.2014.03.029.

Castelló, M. L., Igual, M., Fito, P. J., \& Chiralt, A. (2009). Influence of osmotic dehydration on texture, respiration and microbial stability of apple slices (Var. Granny Smith). Journal of Food Engineering, 91(1), 1-9. https://doi.org/10.1016/j. jfoodeng.2008.07.025.

Ciurzyńska, A., Kowalska, H., Czajkowska, K., \& Lenart, A. (2016). Osmotic dehydration in production of sustainable and healthy food. Trends in Food Science \& Technology, 50, 186-192. https://doi.org/10.1016/j.tifs.2016.01.017.

Deng, Y., \& Zhao, Y. (2008). Effect of pulsed vacuum and ultrasound osmopretreatments on glass transition temperature, texture, microstructure and calcium penetration of dried apples (Fuji). LWT - Food Science and Technology,
41(9), 1575-1585. https://doi.org/10.1016/j.lwt.2007.10.018.

Dermesonlouoglou, E., Zachariou, I., Andreou, V., \& Taoukis, P. S. (2016). Effect of pulsed electric fields on mass transfer and quality of osmotically dehydrated kiwifruit. Food and Bioproducts Processing, 100, 535-544. https://doi.org/10. 1016/j.fbp.2016.08.009.

Fernandes, F. A. N., Gallão, M. I., \& Rodrigues, S. (2008). Effect of osmotic dehydration and ultrasound pre-treatment on cell structure: Melon dehydration. LWT - Food Science and Technology, 41(4), 604-610. https://doi.org/10.1016/j.lwt. 2007.05.007.

Fernandes, F. A. N., Gallão, M. I., \& Rodrigues, S. (2009). Effect of osmosis and ultrasound on pineapple cell tissue structure during dehydration. Journal of Food Engineering, 90(2), 186-190. https://doi.org/10.1016/j.jfoodeng.2008.06.021.

Fernandes, F. A. N., Oliveira, F. I. P., \& Rodrigues, S. (2008). Use of ultrasound for dehydration of papayas. Food and Bioprocess Technology, 1(4), 339-345. https:// doi.org/10.1007/s11947-007-0019-9.

Fernandes, F. A. N., \& Rodrigues, S. (2007). Ultrasound as pre-treatment for drying of fruits: Dehydration of banana. Journal of Food Engineering, 82, 261-267. https:// doi.org/10.1016/j.ultsonch.2008.03.009.

Ferrari, C. C., Sarantópoulos, C. I. G. L., Carmello-Guerreiro, S. M., \& Hubinger, M. D. (2013). Effect of osmotic dehydration and pectin edible coatings on quality and shelf life of fresh-cut melon. Food and Bioprocess Technology, 6(1), 80-91. https://doi.org/10.1007/s11947-011-0704-6.

Fijalkowska, A., Nowacka, M., Wiktor, A., Sledz, M., \& Witrowa-Rajchert, D. (2016) Ultrasound as a pretreatment method to improve drying kinetics and sensory properties of dried apple. Journal of Food Process Engineering, 39(3), 256-265. https://doi.org/10.1111/jfpe.12217.

Fijalkowska, A., Nowacka, M., \& Witrowa-Rajchert, D. (2017). The physical, optical and reconstitution properties of apples subjected to ultrasound before drying. Italian Journal of Food Science, 29(2), 343-356.

Galmarini, M. V., Baeza, R., Sanchez, V., Zamora, M. C., \& Chirife, J. (2011). Comparison of the viscosity of trehalose and sucrose solutions at various temperatures: Effect of guar gum addition. LWT - Food Science and Technology, 44(1), 186-190. https://doi.org/10.1016/j.lwt.2010.04.021.

Gianotti, A., Sacchetti, G., Guerzoni, M. E., \& Dalla Rosa, M. (2001). Microbial aspects on short-time osmotic treatment of kiwifruit. Journal of Food Engineering, 49(2-3), 265-270. https://doi.org/10.1016/S0260-8774(00)00213-2.

Goula, A. M., Kokolaki, M., \& Daftsiou, E. (2017). Use of ultrasound for osmotic dehydration. The case of potatoes. Food and Bioproducts Processing, 105, 157-170. https://doi.org/10.1016/j.fbp.2017.07.008.

Kaymak-Ertekin, F., \& Sultanolu, M. (2000). Modeling of mass transfer during osmotic dehydration of apples. Journal of Food Engineering, 46(4), 243-250.

Kentish, S., \& Ashokkumar, M. (2011). The physical and chemical effect of ultrasound. In H. Feng, G. V. Barosa-Canovas, \& J. Weiss (Eds.), Ultrasound technologies for food and bioprocessing (pp. 1-12). New York: LLC.

Knorr, D., Zenker, M., Heinz, V., \& Lee, D. U. (2004). Applications and potential of ultrasonics in food processing. Trends in Food Science \& Technology, 15(5), 261-266. https://doi.org/10.1016/j.tifs.2003.12.001.

Kowalska, K., \& Olejnik, A. (2016). Beneficial effects of cranberry in the prevention of obesity and related complications: Metabolic syndrome and diabetes - a review. Journal of Functional Foods, 20, 171-181. https://doi.org/10.1016/j.jff.2015.11.001.

Kutyła-Olesiuk, A., Nowacka, M., Wesoły, M., \& Ciosek, P. (2013). Evaluation of organoleptic and texture properties of dried apples by hybrid electronic tongue. Sensors and Actuators B: Chemical, 187. https://doi.org/10.1016/j.snb.2012.10.133.

Mannozzi, C., Tylewicz, U., Chinnici, F., Siroli, L., Rocculi, P., Dalla Rosa, M., et al. (2018). Effects of chitosan based coatings enriched with procyanidin by-product on quality of fresh blueberries during storage. Food Chemistry, 251, 18-24. https://doi.org/10.1016/j.foodchem.2018.01.015.

McClements, D. J. (1995). Advances in the application of ultrasound. Trends in Food Science \& Technology, 6, 293-299.

McKay, D. L., Chen, C. Y. O., Zampariello, C. A., \& Blumberg, J. B. (2015). Flavonoids and phenolic acids from cranberry juice are bioavailable and bioactive in healthy older adults. Food Chemistry, 168, 233-240. https://doi.org/10.1016/j. foodchem.2014.07.062.

Neto, C. C. (2007). Cranberry and blueberry: Evidence for protective effects against cancer and vascular diseases. Molecular Nutrition \& Food Research, 51(6), 652-664. https://doi.org/10.1002/mnfr.200600279.

Nowacka, M., Fijalkowska, A., Dadan, M., Rybak, K., Wiktor, A., \& WitrowaRajchert, D. (2018). Effect of ultrasound treatment during osmotic dehydration on bioactive compounds of cranberries. Ultrasonics, 83, 18-25. https://doi.org/ 10.1016/j.ultras.2017.06.022.

Nowacka, M., Fijalkowska, A., Wiktor, A., Dadan, M., Tylewicz, U., Dalla Rosa, M. et al. (2018). Influence of power ultrasound on the main quality properties and cell viability of osmotic dehydrated cranberries. Ultrasonics, 83, 33-41. https:// doi.org/10.1016/j.ultras.2017.07.014.

Nowacka, M., Fijalkowska, A., Wiktor, A., Rybak, K., Dadan, M., \& WitrowaRajchert, D. (2017). Changes of mechanical and thermal properties of cranberries subjected to ultrasound treatment. International Journal of Food Engineering, 13(6). https://doi.org/10.1515/ijfe-2016-0306.

Nowacka, M., Śledź, M., Wiktor, A., \& Witrowa-Rajchert, D. (2014). Changes of radical scavenging activity and polyphenols content during storage of dried apples. International Journal of Food Properties, 17(6). https://doi.org/10.1080/ 10942912.2012.711408.

Nowacka, M., Tylewicz, U., Laghi, L., Dalla Rosa, M., \& Witrowa-Rajchert, D. (2014) Effect of ultrasound treatment on the water state in kiwifruit during osmotic dehydration. Food Chemistry, 144, 18-25. https://doi.org/10.1016/j.foodchem. 
2013.05.129.

Nowacka, M., Tylewicz, U., Romani, S., Dalla Rosa, M., \& Witrowa-Rajchert, D. (2017). Influence of ultrasound-assisted osmotic dehydration on the main quality parameters of kiwifruit. Innovative Food Science \& Emerging Technologies, 41, 71-78. https://doi.org/10.1016/j.ifset.2017.02.002.

Oszmiański, J., Wojdyło, A., Lachowicz, S., Gorzelany, J., \& Matłok, N. (2016). Comparison of bioactive potential of cranberry fruit and fruit-based products versus leaves. Journal of Functional Foods, 22, 232-242. https://doi.org/10.1016/j.jff. 2016.01.015.

Panarese, V., Tylewicz, U., Santagapita, P., Rocculi, P., \& Dalla Rosa, M. (2012) Isothermal and differential scanning calorimetries to evaluate structural and metabolic alterations of osmo-dehydrated kiwifruit as a function of ripening stage. Innovative Food Science \& Emerging Technologies, 15, 66-71. https://doi. org/10.1016/j.ifset.2012.04.001.

Periche, A., Castelló, M. L., Heredia, A., \& Escriche, I. (2015). Influence of drying method on steviol glycosides and antioxidants in Stevia rebaudiana leaves. Food Chemistry, 172,1-6. https://doi.org/10.1016/j.foodchem.2014.09.029.

Prinzivalli, C., Brambilla, A., Maffi, D., Lo Scalzo, R., \& Torreggiani, D. (2006). Effect of osmosis time on structure, texture and pectic composition of strawberry tissue. European Food Research and Technology, 224(1), 119-127. https://doi.org/10. 1007/s00217-006-0298-9.

Radojčin, M., Babić, M., Babić, L., Pavkov, I., Bukurov, M., Bikić, S., et al. (2015). Effects of osmotic pretreatment on quality and physical properties of dried quinces (Cydonia oblonga). Journal of Food and Nutrition Research, 54(2), 142-154.

Raemy, A., \& Schweizer, T. F. (1983). Thermal behaviour of milk powders studied by differential thermal analysis and heat flow calorimetry. Journal of Therma Analysis, 28, 95-108.

Rajewska, K., \& Mierzwa, D. (2017). Influence of ultrasound on the microstructure of plant tissue. Innovative Food Science \& Emerging Technologies, 43, 117-129. https://doi.org/10.1016/j.ifset.2017.07.034.

Rząca, M., Witrowa-Rajchert, D., Tylewicz, U., \& Rosa, M. D. (2009). Mass exchange in osmotic dehydration process of Kiwi fruits | Wymiana masy w procesie odwadniania osmotycznego owoców Kiwi. Zywnosc. Nauka. Technologia. Jakosc/
Food. Science Technology. Quality, 6(67), 140-149.

Simal, S., Benedito, J., Sánchez, E. S., \& Rosselló, C. (1998). Use of ultrasound to increase mass transport rates during osmotic dehydration. Journal of Food Engineering, 36(98), 323-336. https://doi.org/10.1016/S0260-8774(98)00053-3.

Stojanovic, J., \& Silva, J. L. (2006). Influence of osmotic concentration, continuous high frequency ultrasound and dehydration on antioxidants, colour and chemical properties of rabbiteye blueberries. Food Chemistry, 101(3), 898-906. https://doi.org/10.1016/j.foodchem.2006.02.044.

Teleszko, M. (2011). American cranberry (Vaccinium macrocarpon L.) - possibility of using it to produce bio-food. ŻYWNOŚć. Nauka. Technologia. Jakość, 6(79), $132-141$.

Tylewicz, U., Panarese, V., Laghi, L., Rocculi, P., Nowacka, M., Placucci, G., et al. (2011). NMR and DSC water study during osmotic dehydration of actinidia deliciosa and actinidia chinensis kiwifruit. Food Biophysics, 6(2), 327-333. https://doi.org/10.1007/s11483-011-9210-7.

Tylewicz, U., Tappi, S., Mannozzi, C., Romani, S., Dellarosa, N., Laghi, L, et al (2017) Effect of pulsed electric field (PEF) pre-treatment coupled with osmotic dehydration on physico-chemical characteristics of organic strawberries. Journal of Food Engineering, 213, 2-9. https://doi.org/10.1016/j.jfoodeng.2017.04.028.

Wang S. Y. (2006). Fruits with high antioxidant activity as functional foods. In J. Shi (Ed.), Functional food ingredients and Nutraceuticals: Processing technologies. Boca Raton, FL: Taylor \& Francis Group.. LLC, 2006; 371 pp.

Wiktor, A., Sledz, M., Nowacka, M., Rybak, K, \& Witrowa-Rajchert, D. (2016). The influence of immersion and contact ultrasound treatment on selected properties of the apple tissue. Applied Acoustics, 103(Part B), 136-142. https://doi.org/ 10.1016/j.apacoust.2015.05.001.

Witrowa-Rajchert, D., Wiktor, A., Sledz, M., \& Nowacka, M. (2014). Selected emerging technologies to enhance the drying process: A review. Drying Technology, 32(11), 1386-1396. https://doi.org/10.1080/07373937.2014.903412.

Zenker, M., Heinz, V., \& Knorr, D. (2003). Application of ultrasound-assisted therma processing for preservation and quality retention of liquid foods. Journal of Food Protection, 66(9), 1642-1649. https://doi.org/10.4315/0362-028X-66.9.1642. 